\title{
Extrém méretü cornu cutaneum az alsó ajkon
}

\author{
Esetismertetés
}

\author{
DR. SZABÓ GÁBOR, DR. VIDA GERGELY, DR. FÜLÖP GÁBOR
}

\begin{abstract}
A pácienst évtizedek óta az alsó ajakpíron növekvő, az észleléskor $15 \mathrm{~cm}$-es cornu cutaneummal és fekélyes nyálkahártya elváltozással irányították osztályunkra. CT és PET-CT vizsgálatot követően lineáris excisiót és tumor exstirpatiót végeztünk. A szövettani vizsgálat malignitást igazolt. Azóta a beteget az onko-team döntése alapján szoros kontroll alatt tartjuk, jelenleg is tünet- és panaszmentes.
\end{abstract}

Kulcsszavak: cornu cutaneum, carcinoma labii inferioris, kontrollvizsgálat

\section{Bevezetés}

A cornu cutaneum lassan, fájdalmatlanul növekvő, erösen kiemelkedő szarukúp. Színe lehet piszkosszürke vagy barna. Szívósan tapad az alapjához, panaszt nem okoz. Idősebb egyéneken, főleg férfi mezőgazdasági dolgozók napsütötte bőrfelületén vagy ajkán jelentkezik $[4,6]$. A humán papillomavírus (HPV) fertőzést is etiológiai ágensnek tekintik [1]. Nagysága változó, néhány millimétertől néhány centiméterig terjedhet [5]. A bőrszarv leemelése után papillomatosus, malignitásra gyanús felszínű burjánzás maradhat vissza [4]. Annak ellenére, hogy a bőrszarvak $60 \%$-a jóindulatú, a bőrrák lehetőségét mindig szem előtt kell tartani [5]. Diagnosztizálásában a hisztopathológiai vizsgálat segít [2]. Szövettanilag a nagyfokú hiperkeratózis mellett a hám atrófiás, melyben különböző fokú hámdiszpláziától a „carcinoma in situ"-n keresztül kb. 3-10\%-ban [3, 7] laphámrák is előfordulhat. Klinikailag az ajakráktól nem könynyű megkülönböztetni, bár exophytikus típusa szintén kiemelkedik, de nem olyan mértékben, mint a bőrszarv.

\section{Esetismertetés}

Hetvenkét éves férfibeteg 2018 májusában bőrgyógyászati beutalóval jelentkezett a Kaposi Mór Oktató Kórház szájsebészeti ambulanciáján. Anamnéziséből kiderült, hogy a páciens egyedül, elszigetelten él, mezőgazdasági munkával foglalkozik, sokat tartózkodik szabad levegőn, erős dohányos, gyógyszereket nem szed. Az utóbbi időben kezdte zavarni az ajakelváltozása, ezért jelentkezett vizsgálatra háziorvosánál, aki bőrgyógyászatra irányította.

Klinikai vizsgálat: szimmetrikus arcfelek, állcsontok atrófiásak, alakilag és funkcionálisan épek. Teljes felső

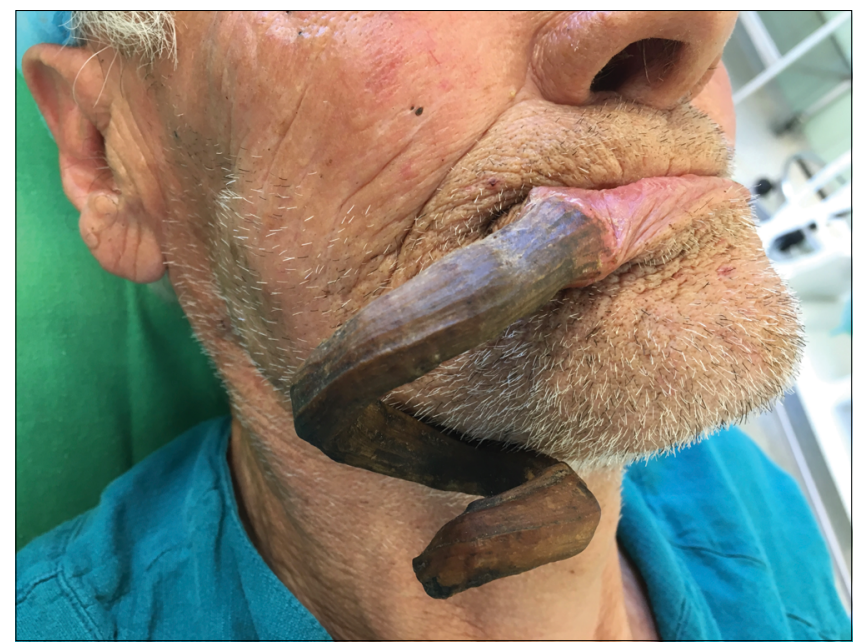

1. kép: Kiindulási állapot

fogatlanság, alul parodontopátiás, hiányos maradékfogazat. Az alsó ajakpíron a középvonaltól jobbra kb. $15 \mathrm{~cm}$ hosszúságú, visszacsavarodó szarumassza, a bal oldali harmadban kb. $10 \times 18$ mm-es tömött alapú kifekélyesedett szövetszaporulat (1. kép). Bal oldaIon submandibularisan megnagyobbodott nyirokcsomó tapintható.

Ki kell emelni, hogy intézményünk gyakorlata szerint általában a biopszia eredményének ismeretében döntjük el, készüljön-e „0-staging” (nyak-mellkas CT) képalkotó vizsgálat. Ettől a gyakorlattól kivételes, egyedi esetben térünk el - mint ahogy ennél az esetnél is történt -, amikor klinikai vizsgálattal igen nagy valószínúséggel malignoma volt valószínúsíthető. Ulcerosus ajakelváltozásnál rutinszerűen nem történik képalkotó vizsgálat a biopszia eredményének ismerete nélkül. 


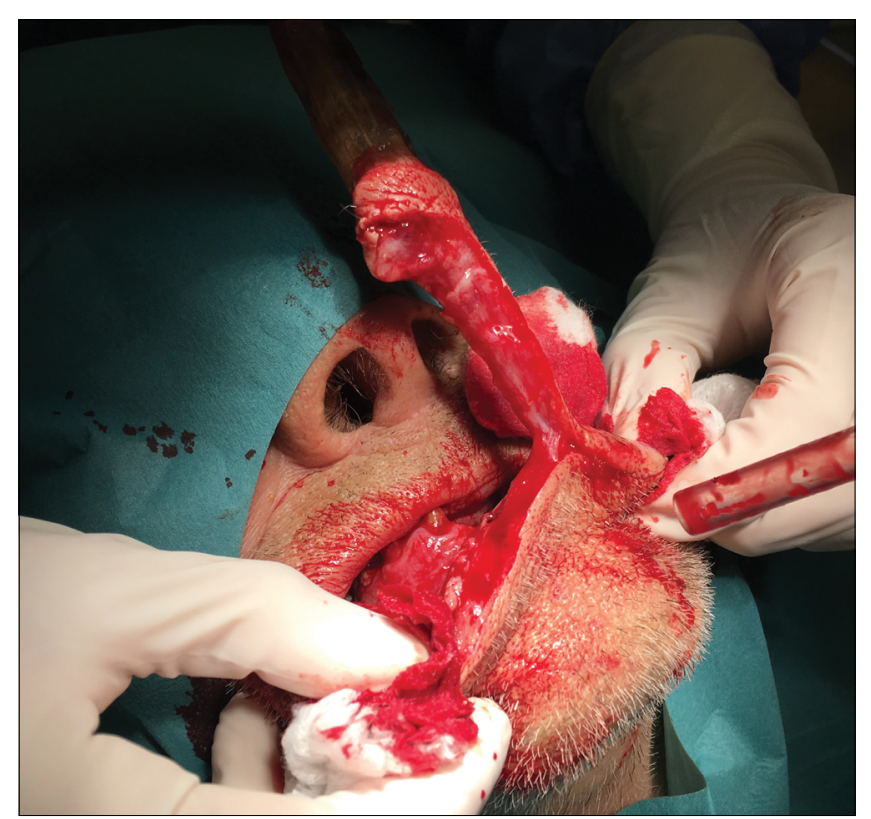

2. kép: Műtéti beavatkozás közben - exstirpatio

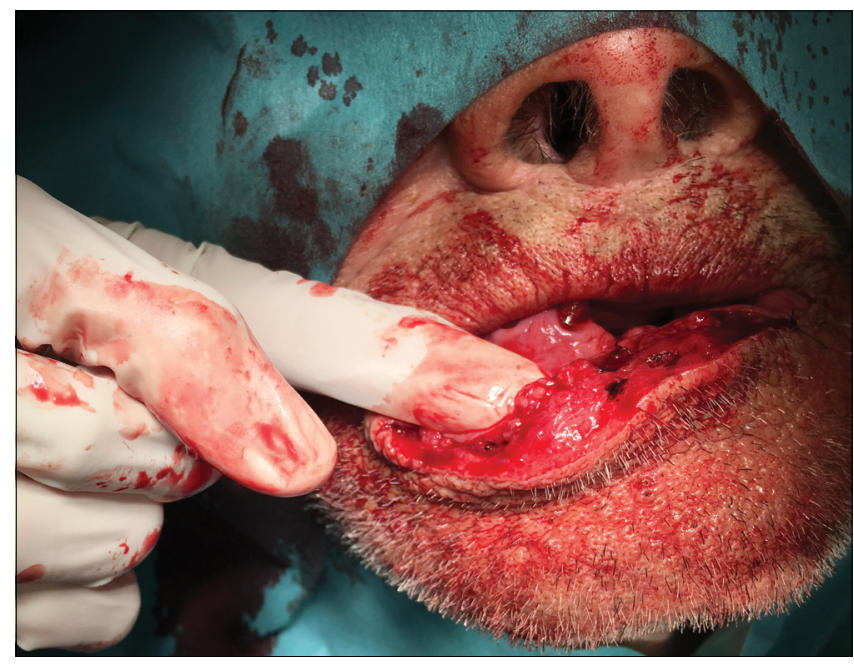

3. kép: Mútéti beavatkozás közben - a defektus zárása előtt

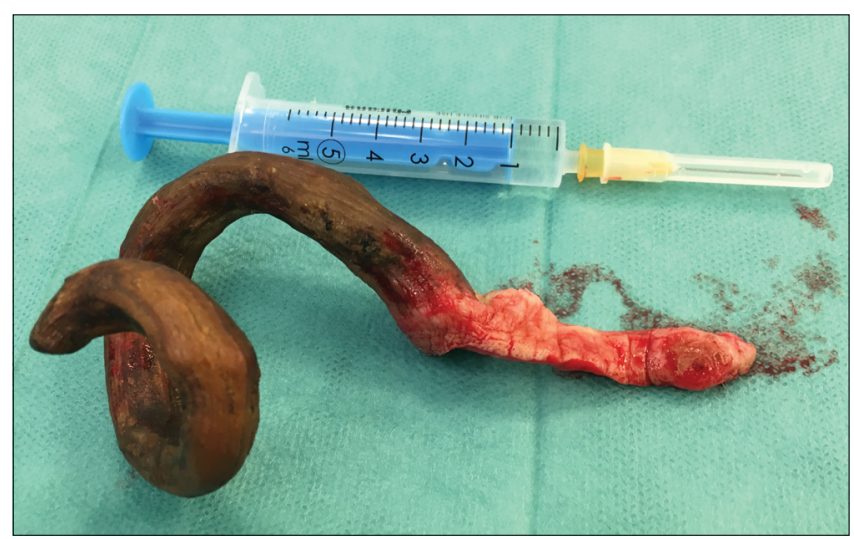

4. kép: Az eltávolított szövet

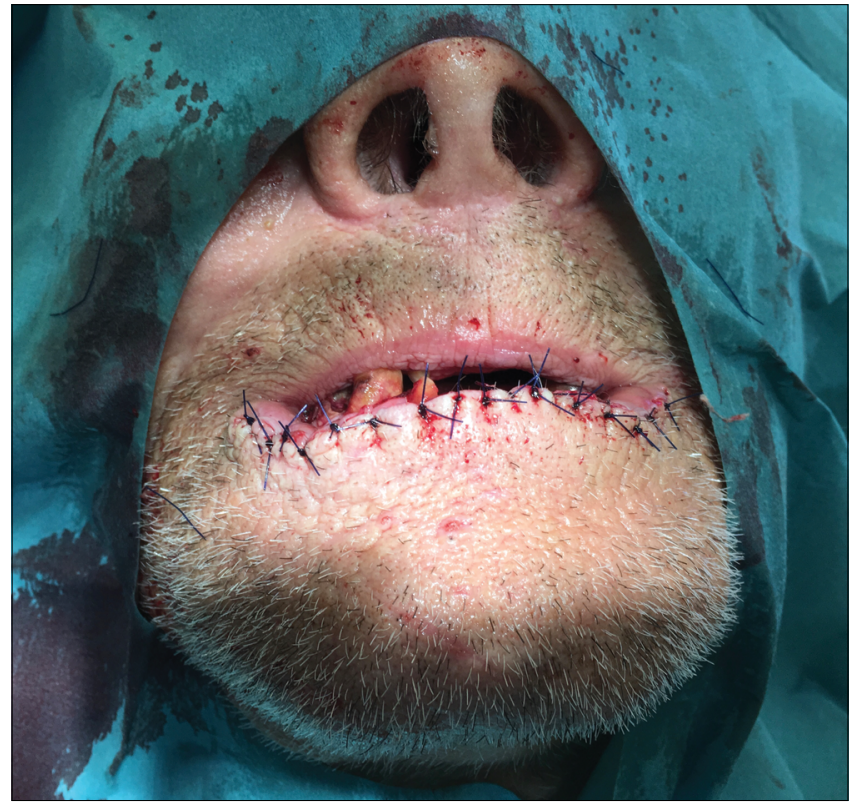

5. kép: Mútét utáni állapot

\section{Radiológiai vizsgálat}

Nyak-mellkas CT vizsgálat: Iv. kontrasztanyag adása után elvégzett vizsgálat klinikailag igazolt ajak térfoglalást írt le. A nyakon kórosan megnagyobbodott nyirokcsomót nem talált. Bal oldalon submandibularisan $7 \mathrm{~mm}$ es nyirokcsomó, a mandibula szöglet mellett a parotistól nem elkülöníthető $9 \mathrm{~mm}$-es nyirokcsomó látható.

\section{PET-CT vizsgálat}

Vélemény: Jelenleg viabilis/reziduális vagy egyértelmú távoli disseminatióra utaló fokális/fokozott FDG halmozás nem ábrázolódik. A nyaki és a mediastino-hilaris régiókban látható fokozott metabolizmusú nyirokcsomók elsősorban reaktív eredetúnek tartandók.

A vizsgálatok lezajlása után a pácienst tájékoztattuk a kóros elváltozásról és annak kezelési lehetőségeiről. A kezelési terv felállítását követően nasotrachealis, intubációs narkózisban teljes alsó ajakpír mélyen az épben történő linearis excisiója történt a szaruszarv eltávolításával (2., 3., 4., 5. kép). A szövettani vizsgálat eredménye: carcinoma planocellulare labii inferioris, grade 1-2 (bal oldali harmad területében), illetve cornu cutaneum (jobb oldali harmad területében).

A műtéti beavatkozást követően az onko-team döntése alapján 3-6-9-12 hónapos kontrollvizsgálatok történtek. A páciens a mútétet követően 3 hónap múlva jelentkezett először ambulanciánkon és ekkor járult hozzá radixainak szanálásához (6., 7. kép).

A páciens jelenleg tünet és panaszmentes. Az elvégzett egyéves kontroll CT vizsgálat változatlan státuszt jelzett. 


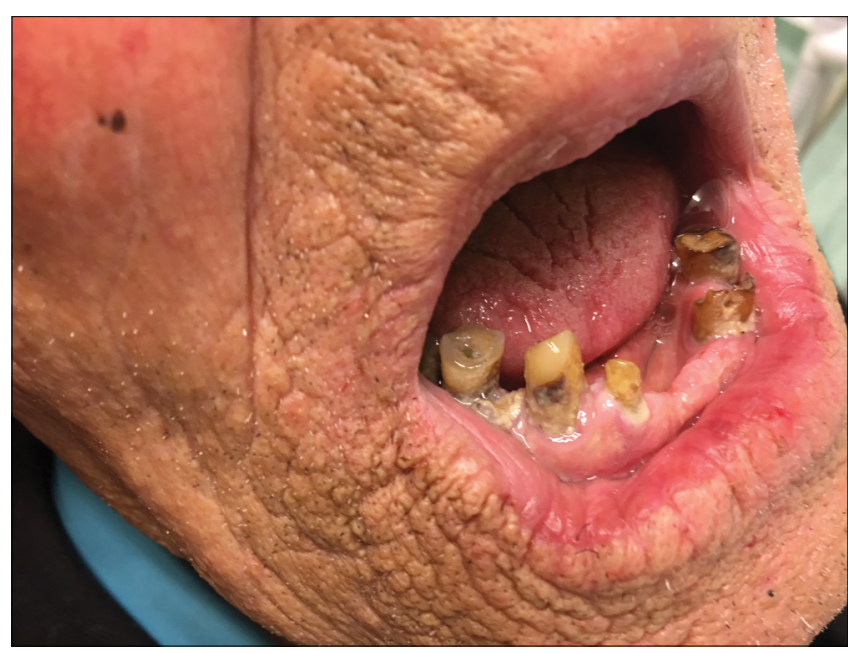

6. kép: 3 hónapos kontroll (fogazat szanálásra szorul)

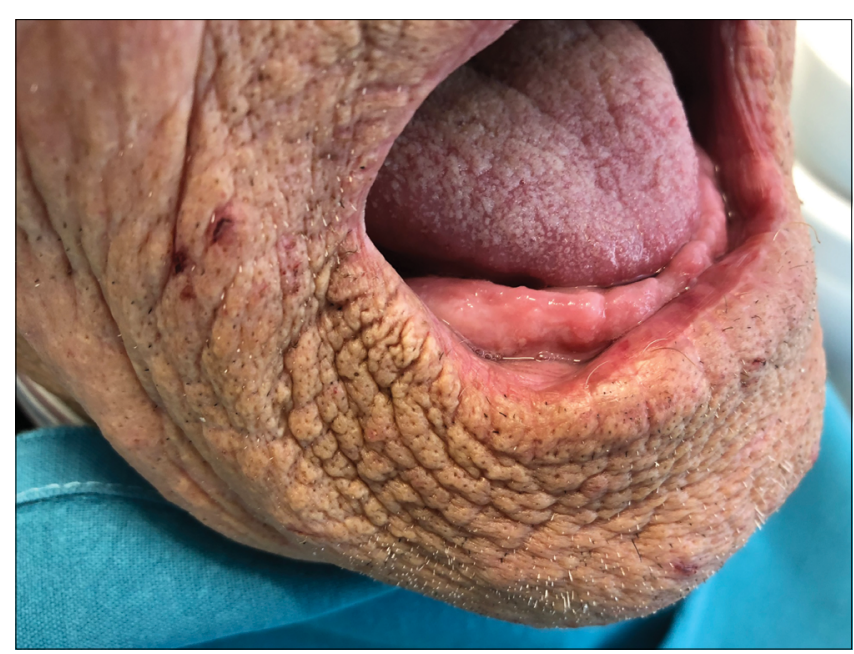

7. kép: 1 éves kontroll (fogazat szanálást követően)

\section{Megbeszélés}

Esetismertetésünkben szereplő páciensnél vélhetően évtizedek óta nem történt orvosi vizsgálat, nem járt semmilyen orvosnál, sem háziorvosnál, sem fogorvosnál, akik észlelték volna a már több centiméteres elváltozást. Az extrém méretű ajakelváltozással csak akkor kereste fel háziorvosát, amikor az már a mindennapi életvitelében zavarta. A mútéti beavatkozás végeztével a páciens nem tekinthető "gyógyult"-nak, a posztoperatív időszakban elengedhetetlen a protokoll szerint végzett rendszeres kontrollvizsgálat, szoros obszerváció.

\section{Irodalom}

1. Agirgol S, Mansur at, Bozkurt K, Azakli hN, Babacan A, Dikmen A: Giant cornu cutaneum superimposed on basal cell carcinoma. West medical J. 2015 Sept; 64 (4): 438-440. https://doi.org/10 .7727/wimj.2014.056

2. Bizakis JG, Manios A, Karatzanis AD, Drivas E, Malandrakis S: Giant cornu cutaneum. Otolaryngol Head Neck Surg. 2005 Oct; 133 (4): 645. https://doi.org/10.1016/j.otohns.2004.09.109

3. BöHnel P, Ehrensperger K: A rare case of cornu cutaneum. Praxis (Bern 1994); 2007 Aug 15; 96 (33): 1223-1224. https://doi.org/10 $.1024 / 1661-8157.96 .33 .1223$

4. LAPIS K: Pathológia. Medicina Kiadó, Budapest 1989; 348-349.

5. Phulari RG, Rathole R, Talegaon TP, Shah A: Cutaneous horn: A mask to underlying malignancy. J Oral Maxillofac Pathol. 2018 Jan 22 (Suppl 1); S87-90. https://doi.org/10.4103/jomfp.JOMFP_ 156_17

6. SALLAY K: Szájbetegségek. Medicina Kiadó, Budapest 1984; 195-196.

7. VÁmosi I, Berényı B, Inovay J: Szájsebészet. Medicina Kiadó, Budapest 1980; 276.

\section{Case report}

\section{SzABÓ G, VIDA G, FüLÖP G}

\section{Giant cornu cutaneum on the lower lip}

\section{A case report}

The 72-year-old male patient came to the oral surgical department of Kaposi Mór Educational Hospital in May 2018 complaining about a 15-centimetre big cornu cutaneum on the right side of the lower lip, which had been growing there for decades. In addition ulcerated mucous membrane lesions were recognisable on the left side of his lip.

After examining and diagnosing the patient's mucous membrane lesions (CT, PET-CT-screening, scaling, radix removal) we deeply resected them from the intact part with linear excision. The results of the biopsy were Grade 1-2 squamous cell cc. of the lower (in the left third of the lip) as well as cornu cutaneum (in the right third of the lip). Thus according to the decision of the oncological team, the patient is under tight control (medical check-up every 3-6-9-12 month). Currently the patient is symptom and complaint-free, and his regular follow-up indicates unchanged status.

Keywords: cornu cutaneum, squamous cell cc. of the lower lip, tight control 